\begin{tabular}{c|c|c}
\hline \hline $\begin{array}{c}\text { Vol. 36(2):199-208 } \\
\text { http://dx.doi.org/10.4217/OPR.2014.36.2.199 }\end{array}$ & Ocean and Polar Research & June 2014 \\
\hline \hline
\end{tabular}

\title{
Note
}

\section{Selection of Copepods as Live Food for Marine Fish Larvae Based on Their Size, Fecundity, and Nutritional Value}

\author{
Sung Jin Yang and Sung Bum Hur* \\ Department of Marine Bio-materials and Aquaculture, College of Fisheries Sciences \\ Pukyong National University, Busan 608-737, Korea
}

\begin{abstract}
Copepods are a major food source for marine fish larvae in nature. Many studies on copepods culture have been conducted to develop a new live food for the seedling production of marine fish larvae. But fish farmers still depend on rotifer and Artemia nauplii. This study was carried out to find suitable copepods as live food for the larvae in hatchery. Eight species of copepods ( 1 calanoid, 2 cyclpoid, 5 harpacticoid) that were fed Isochrysis galbana were examined in terms of the size of nauplii, fecundity, amino acids, and fatty acids contents. These species were divided into small (nauplii length 46-86 $\mu \mathrm{m}$ ) and large (nauplii length 120-188 $\mu \mathrm{m}$ ) size group. Nitokra spinipes in the small group and Tigriopus japonicus in the large group showed the highest fecundity with 151.1 and 139.6 nauplii production per gravid female, respectively. With regard to nutrients, essential amino acids were the highest with $21.2 \%$ in cyclopoid Paracyclopina nana in the small group and n-3 HUFA were the highest in calanoid Pseudodiaptomus inopinus $(8.5 \mu \mathrm{g} / \mathrm{mg})$ in the large group and P. nana $(8.8 \mu \mathrm{g} / \mathrm{mg})$. In terms of the size, fecundity, and nutritional value of copepods examined in this study, $N$. spinipes and $P$. nana seem to be suitable copepod species to develop as a new live food for small mouth fish larvae.
\end{abstract}

Key words : copepods, fecundity, live food, nauplii size, nutrient

\section{Introduction}

Many microalgal species are secured as live food for marine larval culture in the hatchery but zooplankton is limited only to rotifer Brachionus spp. and Artemia. These species have been widely used in seedling production of marine fish larvae because they have the advantage of being easily stored and culture. However, in these species, contents of n-3 highly unsaturated fatty acids (HUFA) such as eicosapentaenoic acid (C20:5n3, EPA) and docosahexaenoic acid (C22:6n3, DHA), which are essential fatty acids for marine fish lavae are low. Thus, nutritional enrichment is required for these species. In addition, their body sizes are usually too large to make them viable targets for capture for fish lavae whose mouth sizes are small such as groupers Epinephelus septemfasciatus and rock sea-bream Oplegnathus fasciatus (Doi et al.

\footnotetext{
*Corresponding author. E-mail : hurs@pknu.ac.kr
}

1997; Toledo et al. 1999; Yoo and Hur 2002; Rajkumar and Kumaraguru 2006).

Basically rotifers that inhabit freshwater or brackish water and Artemia that inhabit salt ponds or salt lakes are not oceanic zooplankton. Therefore, for the seedling production of various marine fish, there is a need to develop natural zooplankton as live food that inhabits the ocean. Copepods play an important role as a food source for larvae in the marine food chain. Especially, they have a higher nutritional value in terms of DHA, EPA, vitamin B1, etc. than rotifer and Artemia (Sargent and Henderson 1986; Fraser et al. 1989; Evjemo et al. 2003). Copepods are also a highly diverse species and they grow through several stages from nauplii till adults. They also come in large sizes and are suitable for feeding purposes (Holt 2003; Fleeger 2005). Therefore, copepods are known to be suitable live food in the seedling production of the larvae (Nanton and Castell 1998; Pinto et al. 2001; Rajkumar and Kumaraguru 2006). However, the use of 
copepods as live food through large scale culture has not been commercialized yet though copepods directly collected from natural water have been used as a larval food for Atlantic halibut Hippoglossus hippoglossus and Atlantic cod Gadus morhua (Naess et al. 1995; Berg 1997). Therefore, this study aimed to uncover basic information in order to promote the mass culture of suitable copepod species that can be substituted for rotifer and Artemia nauplii in the hatchery by analyzing the size, fecundity, and nutritional values of marine copepod species.

\section{Materials and Methods}

\section{Culture and size measurement of copepods}

The copepods used in the experiment were 8 species ( 1 calonoid species, 5 harpacticoid species, and 2 cyclopoid species) obtained from Culture Collection of Useful Marine Plankton (CCUMP), Pukyung National University (Table 1). The copepods were cultured with Isochrysis galbana (KMMCC12) obtained from Korea Marine Microalgae Culture Center (KMMCC) in $2 \mathrm{~L}$ beakers with $1 \mathrm{~L}$ volume. This microalgal species was cultured in the $\mathrm{f} / 2$ medium (Guillard and Ryther 1962 ) at $20^{\circ} \mathrm{C}$ under continuous illumination of $80 \mu \mathrm{mol}$ photons $\mathrm{m}^{-2} \mathrm{~s}^{-1}$ in $20 \mathrm{~L}$ carboy bottles.

The salinity of the copepod culture was adjusted with filtered sea water and distilled water as per the salinity of the site at the time of collection and the culture was maintained at $24^{\circ} \mathrm{C}$ with continuous illumination of $20 \mu \mathrm{mol}$ photons $\mathrm{m}^{-2} \mathrm{~s}^{-1}$. The microalgal concentration was maintained at around $80 \times 10^{4}$ cells $/ \mathrm{mL}$ in the culture water by supplying sufficient foods once a day. Newly hatched (1st stage) of the copepod nauplii and gravid female were separately collected using a 100-180 $\mu \mathrm{m}$ sieve and body length and body width from 50 individuals were measured using a microscope in $\mu \mathrm{m}$ unit. The body length was measured from the end of head to the end of furca, whereas body width was measured as the broadest cephalothorax.

\section{Fecundity of female copepods}

Each copepod species was contained in a 12 hole cell chamber with $5 \mathrm{~mL}$ of culture water to accommodate a gravid female in a hole with 6 replications. And the culture was maintained under the same culture conditions until the copepod died. Counting of nauplii was performed with a microscope by collecting the reproduced nauplii with a micropipette at the same time every day. The reproduced nauplii, reproductive periods, and survival days of a gravid female were examined.

\section{Analysis of amino acids and fatty acid}

The copepods used in the experiments were mass cultured in a $20 \mathrm{~L}$ vessel using the same culture method. Only adults were harvested using a sieve (120-300 $\mu \mathrm{m})$ as per the size of each species. Harvested samples were rinsed with distilled water, filtered through $\mathrm{GF} / \mathrm{C}$ filter $(0.45 \mu \mathrm{m})$, and then stored at $-80^{\circ} \mathrm{C}$ until further analysis was performed. Meanwhile, rotifer and Artemia nauplii were also cultured as a control. The rotifer used as a control was Brachionus plicatilis (CCUMP46) obtained from CCUMP. It was cultured at $24^{\circ} \mathrm{C}$ and 20 psu with the same feeding conditions as applied in copepods culture. Artemia cysts from INVE (Great Salt Lake, USA) were hatched with filtered seawater at $20^{\circ} \mathrm{C}$ and nauplii were immediately harvested. They were stored using the same storage methods for the copepods and then used for amino acid and fatty acid analysis.

For amino acids analysis, $20 \mathrm{mg}$ of sample infused with $15 \mathrm{~mL}$ of $6 \mathrm{~N} \mathrm{HCl}$ was heated, sealed, and hydrolyzed at $110^{\circ} \mathrm{C}$ for $24 \mathrm{~h}$. The sample was then filtered and dried to

Table 1. Source of the copepods for the study

\begin{tabular}{|c|c|c|c|c|c|}
\hline Order & Species & CCUMP $^{1}$ No. & Sampling area & Habitat & Salinity (psu) \\
\hline Calanoid & Pseudodiaptomus inopinus & 5 & Yeonggwang & Salt pond & 16 \\
\hline \multirow[t]{5}{*}{ Harpacticoid } & Tachdius triangularis & 83 & Buan & Lagoon & 6 \\
\hline & Tigriopus japonicus & 23 & Haeundae & Tidal pool & 33 \\
\hline & Amphiascus sp. & 30 & Hwajinpo & Lagoon & 17 \\
\hline & Nitokra spinipes & 29 & Songji Lake & Lagoon & 10 \\
\hline & Tisbe teuera & 65 & Yongho Bay & Marine & 34 \\
\hline \multirow[t]{2}{*}{ Cyclopoid } & Paracyclopina nana & 70 & Wangpo & Estuary & 15 \\
\hline & Apocyclops sp. & 20 & Taean & Salt pond & 19 \\
\hline
\end{tabular}

${ }^{1}$ CCUMP: Culture Collection of Useful Marine Plankton 
remove $\mathrm{HCl}$. Twenty-five $\mathrm{mL}$ and the sample was set by sodium dilution buffer $(\mathrm{pH}$ 2.2) and a portion of the sample was analyzed by ninhydrin method using amino acid analyzer (HSAAA, Hitachi L-8800, Japan). Conditions of the analysis were as follows: column size, $4 \times 150 \mathrm{~mm}$; absorbance level, $570 \mathrm{~nm}$ and $440 \mathrm{~nm}$; reagent flow rate, $0.25 \mathrm{~mL} / \mathrm{min}$; buffer flow rate, $0.45 \mathrm{~mL} / \mathrm{min}$; reactor temperature, $120^{\circ} \mathrm{C}$; reactor size, $15 \mathrm{~m}$; and analysis time, $65 \mathrm{~min}$.

For the analysis of fatty acids, $20 \mathrm{mg}$ of a sample in a $15 \mathrm{~mL}$ flask was added to $2 \mathrm{~mL}$ of $10 \% \mathrm{BF}_{3}$-methanol. Nitrogen was added to the sample and heated at $85^{\circ} \mathrm{C}$ for an hour and a half to draw out methyl ester (Morrison and Smith 1964; Budge 1999). A gas chromatography (HP 6890N; Agilent, Santa Clara, CA, USA) equipped with an Auto Sampler (Agilent) was used for fatty acid analysis. A w-wax column (30 m long, 0.25 mm I.d., $0.25 \mu \mathrm{m}$ film thickness; Supelco, Bellefonte, PA, USA) was used for separations. Nitrogen was used as the carried gas and the flow rate was set at $30 \mathrm{~mL} \mathrm{~min}^{-1}$. The column temperature profile was the same: standing at $200^{\circ} \mathrm{C}$ for $3 \mathrm{~min}$, increase to $1^{\circ} \mathrm{C} \mathrm{min}$ from 200 to $230^{\circ} \mathrm{C}$, and then hold at $230^{\circ} \mathrm{C}$ for $25 \mathrm{~min}$. Temperature of injector was $250^{\circ} \mathrm{C}$ and flame ionization with the detector (FID) was held at $250^{\circ} \mathrm{C}$. Fatty acid peaks were integrated using HP-6890. Gas chromatography software was utilized and identification was made with reference to known standards (PUFA 37 component FAME Mix; Supelco).

\section{Statistical analysis}

The results were analyzed by one-way ANOVA and Duncan's multiple range test (Duncan 1955) was applied for the significance level $(P<0.05)$. The SPSS version 17 (SPSS Inc., Chicago, IL, USA) program was used for all statistical analyses.

\section{Results}

\section{Size of nauplii and adults}

The sizes of nauplii and adult copepods are shown in Table 2. Copepods were classified into 5 species of a small group and 3 species of a large group. In the small group, the size of nauplii was $45.9-85.6 \mu \mathrm{m}$ in terms of body length and 42.2-87.7 $\mu \mathrm{m}$ in terms of body width and the size of adults was 431.9-657.6 $\mu \mathrm{m}$ in terms of body length and 125.2-238.4 $\mu \mathrm{m}$ in terms of body width. The body length of Nitokra spinipes nauplii was the smallest at $45.9 \mu \mathrm{m}$ and Tisbe teuera nauplius was the largest with a body length of $85.6 \mu \mathrm{m}(P<0.05)$. The smallest body width was found in Paracyclopina nana with a body width of $42.2 \mu \mathrm{m}$, and the largest in Amphiascus sp. with $87.7 \mu \mathrm{m}$. The smallest body length of adults was found in Tachidius triangularis with a body length of $431.9 \mu \mathrm{m}(P$ $<0.05)$ and the largest body length was found among $T$. teuera with $657.6 \mu \mathrm{m}$, but the difference was not significant when compared with that of Amphiascus sp. $(656.0 \mu \mathrm{m})$. In the case of body width, the smallest was found in $N$. spinipes with $125.2 \mu \mathrm{m}$, whereas the largest was found in $T$. teuera with $238.4 \mu \mathrm{m}(P<0.05)$.

In the large group, the range of body length and body width for nauplii were between 119.7-187.7 $\mu \mathrm{m}$ and 86.1$101.7 \mu \mathrm{m}$, respectively, while those of the adults were 832.0-1157.8 $\mu \mathrm{m}$ and 311.6-341.7 $\mu \mathrm{m}$, respectively. The body length of Tigriopus japonicus nauplii was the smallest with $119.7 \mu \mathrm{m}$, whereas that of Pseudodiaptomus inopinus was the largest with $187.7 \mu \mathrm{m}$. The body width of $T$. japonicus was the widest with $101.7 \mu \mathrm{m}$ and the smallest was found in Apocyclops sp. with $86.1 \mu \mathrm{m}$. The smallest body length of adults was found in $T$. japonicus with $832.0 \mu \mathrm{m}$ and the largest was in $P$. inopinus with $1157.8 \mu \mathrm{m}(P<0.05)$. The smallest body width was $T$.

Table 2. Size of nauplius and adult of the copepods in the study

\begin{tabular}{|c|c|c|c|c|c|}
\hline \multirow{2}{*}{$\begin{array}{c}\text { Size } \\
\text { group }\end{array}$} & \multirow{2}{*}{ Species } & \multicolumn{2}{|c|}{ Nauplius } & \multicolumn{2}{|c|}{ Adult } \\
\hline & & Body length $(\mu \mathrm{m})$ & Body width $(\mu \mathrm{m})$ & Body length $(\mu \mathrm{m})$ & Body width $(\mu \mathrm{m})$ \\
\hline \multirow[t]{5}{*}{ Small } & Tachidius triangularis & $76.8 \pm 8.8^{\mathrm{d}}$ & $59.2 \pm 6.2^{\mathrm{f}}$ & $431.9 \pm 16.9^{g}$ & $166.2 \pm 7.1^{\mathrm{f}}$ \\
\hline & Amphiascus sp. & $58.8 \pm 7.9^{\mathrm{e}}$ & $87.7 \pm 8.7^{\mathrm{c}}$ & $656.0 \pm 14.9^{d}$ & $135.0 \pm 10.3^{\mathrm{g}}$ \\
\hline & Nitokra spinipes & $45.9 \pm 5.9^{f}$ & $64.5 \pm 6.0^{\mathrm{e}}$ & $519.9 \pm 24.4^{\mathrm{f}}$ & $125.2 \pm 8.0^{\mathrm{h}}$ \\
\hline & Tisbe teuera & $85.6 \pm 11.3^{\mathrm{c}}$ & $70.8 \pm 9.8^{\mathrm{d}}$ & $657.6 \pm 28.0^{\mathrm{d}}$ & $238.4 \pm 10.3^{\mathrm{d}}$ \\
\hline & Paracyclopina nana & $81.9 \pm 6.5^{\mathrm{d}}$ & $42.2 \pm 5.2^{\mathrm{g}}$ & $537.4 \pm 31.9^{\mathrm{e}}$ & $178.2 \pm 13.4^{\mathrm{e}}$ \\
\hline \multirow[t]{3}{*}{ Large } & Pseudodiaptomus inopinus & $187.7 \pm 8.3^{\mathrm{a}}$ & $93.8 \pm 10.2^{b}$ & $1157.8 \pm 53.6^{\mathrm{a}}$ & $330.7 \pm 22.4^{b}$ \\
\hline & Tigriopus japonicus & $119.7 \pm 9.8^{\mathrm{b}}$ & $101.7 \pm 10.0^{\mathrm{a}}$ & $832.0 \pm 27.6^{\mathrm{c}}$ & $311.6 \pm 8.6^{\mathrm{c}}$ \\
\hline & Apocyclops sp. & $122.7 \pm 10.2^{\mathrm{b}}$ & $86.1 \pm 7.0^{\mathrm{c}}$ & $1017.4 \pm 44.0^{\mathrm{b}}$ & $341.7 \pm 18.3^{\mathrm{a}}$ \\
\hline
\end{tabular}

Values in the same column not sharing a common superscript mean significantly different $(P<0.05)$ 

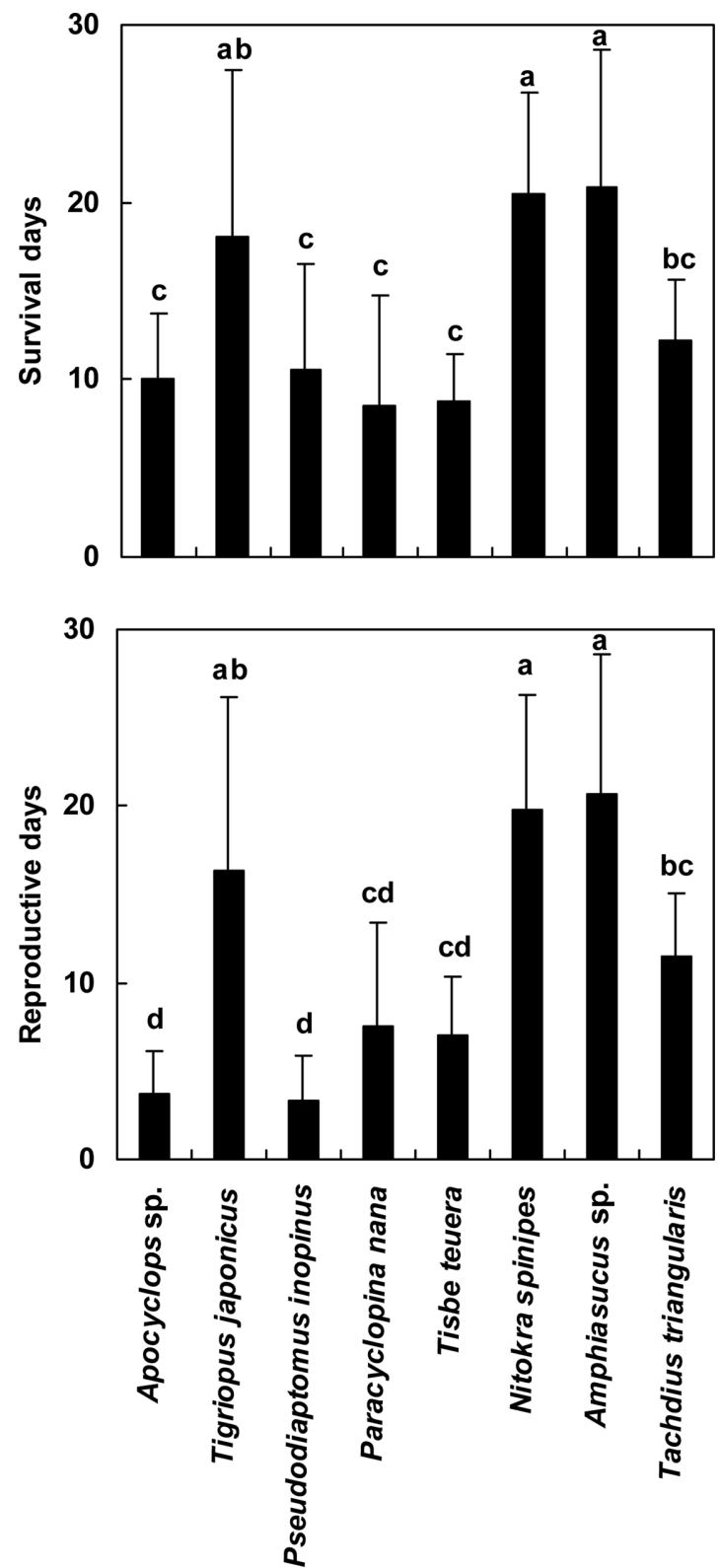

Fig. 1. Survival (up) and reproductive days (bottom) of a gravid female of copepods. Different letters on the bar mean significantly difference $(P<0.05)$

japonicus with $311.6 \mu \mathrm{m}$ and the largest in Apocyclops sp. with $341.7 \mu \mathrm{m}(P<0.05)$.

\section{Survival days and fecundity}

Survival and nauplii production days of a gravid female are presented in Fig. 1. In the small group, the longest survival period was found in Amphiascus sp. and $N$. spinipes with 20.8 days and 20.5 days, respectively, whereas the shortest survival period was found in T. teuera and $P$. nana with 8.8 days and 8.5 days, respectively. Nauplii
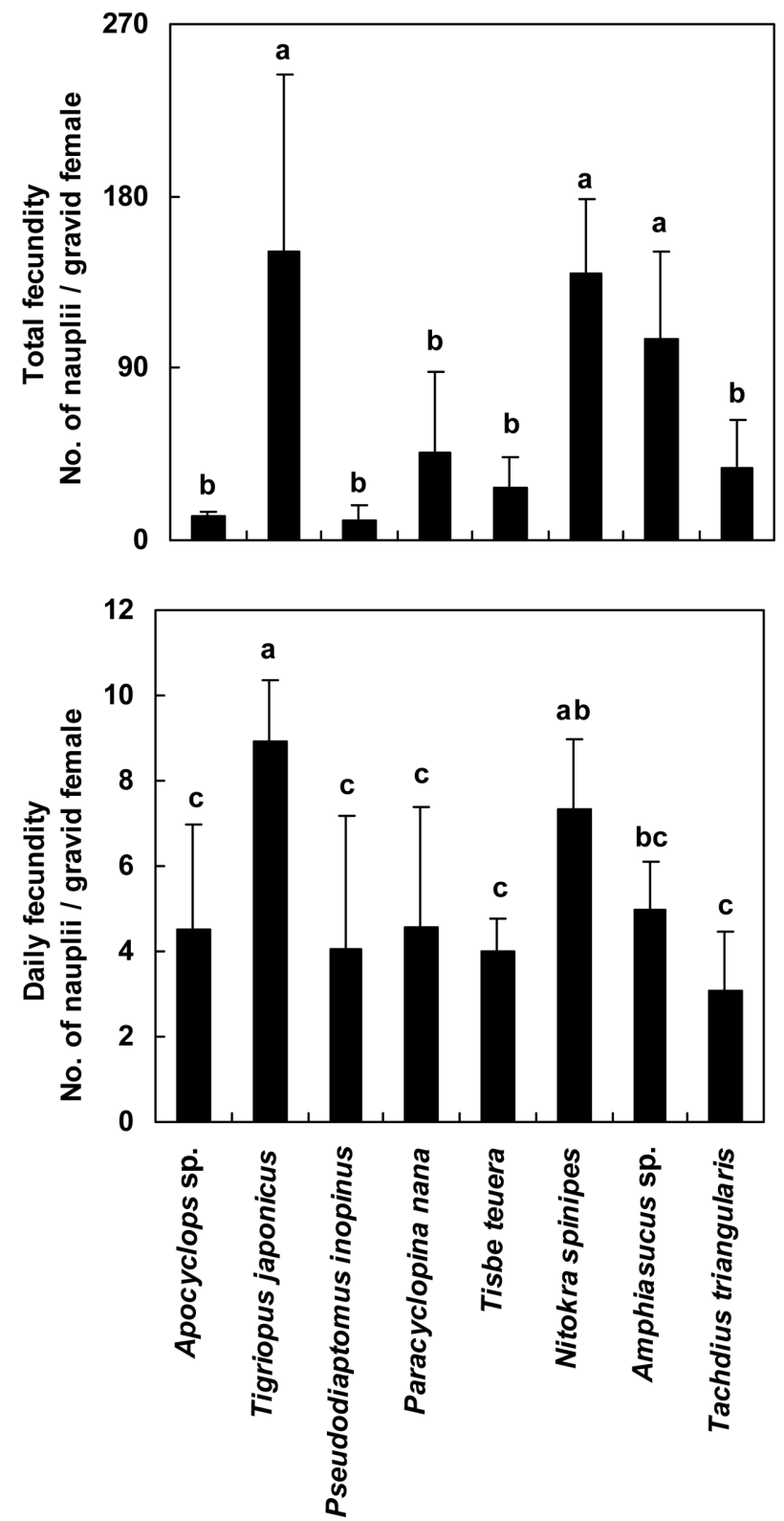

Fig. 2. Total (up) and daily fecundity (bottom) per gravid female of copepods. Different letters on the bar mean significantly difference $(P<0.05)$

production days were the longest in Amphiascus sp. and $N$. spinipes with 20.6 days and 19.8 days each respectively, whereas the shortest periods were in $P$. nana and T. teuera with 7.5 days and 7.0 days, respectively, which revealed a similar trend to that detected for survival periods. In the large group, the longest survival period was in $T$. japonicus with 18 days and the shortest was in $-P$. inopinus and Apocyclops sp. with 10.5 days and 10 days each $(P<$ 0.05 ). Similar to survival periods, nauplii production days were the longest in $T$. japonicus at 16.3 days, whereas 
Apocyclops sp. (3.7 days) and $P$. inopinus (3.3 days) showed significantly shorter nauplii production periods $(P$ $<0.05)$.

Fecundity per gravid female is presented in Fig. 2. The total number of nauplii produced per gravid female was the highest with 151.2 in the $T$. japonicus in large group, followed by $N$. spinipes (139.7 nauplii) and Amphiascus sp. (105.1 nauplii) in the small group. Total fecundity in the rest of the 5 species was in a range of 10-45 nauplii, but with no significant differences among them. The fecundity of Apocylops sp. and P. inopinus in large group was the least with 12.3 and 10.8 nauplii, respectively.

T. japonicus in the large group also showed the highest daily average fecundity with 8.9 nauplii followed by $N$. spinipes in the small group with 7.3 nauplii. Daily average fecundity was the least in T. triangularis (3.1 nauplii) in the small group and $P$. inopinus (4.0 nauplii) in the large group, which was similar to trends regarding nauplii production days.

\section{Amino acids and fatty acids composition}

The composition of amino acids from 8 copepods species along with that of the control B. plicatilis and Artemia nauplii are presented in Table 3. Glutamic acid was the highest at $47-68 \mu \mathrm{g} / \mathrm{mg}$, whereas cysteine was the lowest at $2-3 \mu \mathrm{g} / \mathrm{mg}$. Cysteine was not detected in $P$. nana. In all copepods other than $P$. nana, arginine, leucine, and lysine among essential amino acids were high as 27$35 \mu \mathrm{g} / \mathrm{mg}, 24-37 \mu \mathrm{g} / \mathrm{mg}$, and 23-34 $\mu \mathrm{g} / \mathrm{mg}$, respectively. Artemia nauplii had the highest glutamic acid contents at $37.5 \mu \mathrm{g} / \mathrm{mg}$, but this value was significantly lower compared with those of other copepods $(P<0.05)$. Artemia nauplii also showed low cystein contents at $2.6 \mu \mathrm{g} / \mathrm{mg}$, which was similar trend with other copepods. However, $B$. plicatilis revealed a somewhat different trend with regard to amino acid composition from Artemia nauplii - having the highest glutamic acid content at $58.1 \mu \mathrm{g} / \mathrm{mg}$ and methionine at $1.5 \mu \mathrm{g} / \mathrm{mg}$.

It was found that the essential amino acid composition was significantly higher in $P$. nana at $21.2 \%$ compared to other species $(P<0.05)$. A relatively higher amount of essential amino acids composition was found in $B$. plicatilis at $19.8 \%$, while the lowest level was found in Artemia nauplii at $14 \%(P<0.05)$. Among the copepods, the essential amino acid was the lowest in $T$. japonicus and Amphiascus sp. at 15\%. Total protein composition was the highest in $P$. nana at $51.3 \%$ followed by $P$. inopinus and Apocyclops sp. The protein composition of other copepods was in a range of $37-43 \%$. The protein composition in the control Artemia nauplii was significantly lower at $31.5 \%$ compared with that of the other species, whereas the protein composition of the other control, $B$. plicatilis, was $48.1 \%$, which was similar to that of $P$. inopinus. Total protein composition in copepods was far higher than that of Artemia nauplii.

The fatty acid composition of 8 species of copepod and two controls B. plicatlis and Artemia nauplius are shown in Table 4. Fatty acid C17:0 content among 7 copepods species except $N$. spinipes, which between $2.7-5.2 \mu \mathrm{g} / \mathrm{mg}$ in dry weight. But that of Artemia nauplii was high at $4.0 \mu \mathrm{g} / \mathrm{mg}$ and that of B. plicatilis was low at $2.0 \mu \mathrm{g} / \mathrm{mg}$. Stearic acid (18:0) content was as the highest in P. nana at $2.9 \mu \mathrm{g} / \mathrm{mg}$, while that of the other species was in a range of $1.0-2.2 \mu \mathrm{g} / \mathrm{mg}$. Stearic acid was not detected in $B$. plicatilis. The content of linoleic acid (18:2n6) and $\alpha$ linolenic acid (18:3n3) in $P$. nana was significantly higher at $4.3 \mu \mathrm{g} / \mathrm{mg}$ and $3.0 \mu \mathrm{g} / \mathrm{mg}$, respectively. The $\alpha$-linolenic acid in Artemia nauplii was $2.6 \mu \mathrm{g} / \mathrm{mg}$ which was not significantly different from that of $P$. inopinus and $P$. nana, but this value was significantly higher in comparison to that of $B$. plicatilis $(1.7 \mu \mathrm{g} / \mathrm{mg})$. The particular distribution characteristics of $\gamma$-linolenic acid (18:3n6) was observed and while Artemia nauplii showed the highest $\gamma$-linolenic acid content at $7.1 \mu \mathrm{g} / \mathrm{mg}$, this fatty acid content was very low in the other species -in a range of $1.4-2.8 \mu \mathrm{g} / \mathrm{mg}$.

Arachidonic acid (AA, 20:4n6) content was found only in Artemia nauplii and Amphiascus sp. at less than $0.6 \mu \mathrm{g} /$ mg. But EPA was found among all the experimental plots. While T. triangularis and two controls showed low EPA in a range of $0.6-0.9 \mu \mathrm{g} / \mathrm{mg}, P$. nana, $P$. inopinus, and $T$. japonicas showed high EPA in a range of $1.7-1.8 \mu \mathrm{g} / \mathrm{mg}$. DHA content was significantly higher in $P$. nana at $4.3 \mu \mathrm{g} / \mathrm{mg}(P<0.05)$, followed by $P$. inopinus at $3.8 \mu \mathrm{g} /$ mg. DHA content was also low in B. plicatilis at $1.1 \mu \mathrm{g} /$ mg, and it was not detected in Artemia nauplii.

The content of saturated fatty acids was significantly higher in $P$. nana at $15 \mu \mathrm{g} / \mathrm{mg}$ among all the experimental plots $(P<0.05)$ and $P$. inopinus showed the next highest fatty acid content at $12.1 \mu \mathrm{g} / \mathrm{mg}$. The content of these acids in Artemia nauplii was relatively higher at $8.5 \mu \mathrm{g} /$ $\mathrm{mg}$ in comparison with that of $B$. pilicatilis at $4.2 \mu \mathrm{g} / \mathrm{mg}$. The content of monounsaturated fatty acids was the highest in Artemia nauplii at $11.9 \mu \mathrm{g} / \mathrm{mg}$, and there was no significant difference in the other species with readings between $0.9-3.3 \mu \mathrm{g} / \mathrm{mg}(P<0.05)$. The content of polyunsaturated fatty acids (PUFA) was significantly higher in $P$. nana, $P$. inopinus, and Artemia nauplii - in a range of $13.7-15.5 \mu \mathrm{g} / \mathrm{mg}$ - than other species $(8.2-10.8 \mu \mathrm{g} / \mathrm{mg})(P$ 


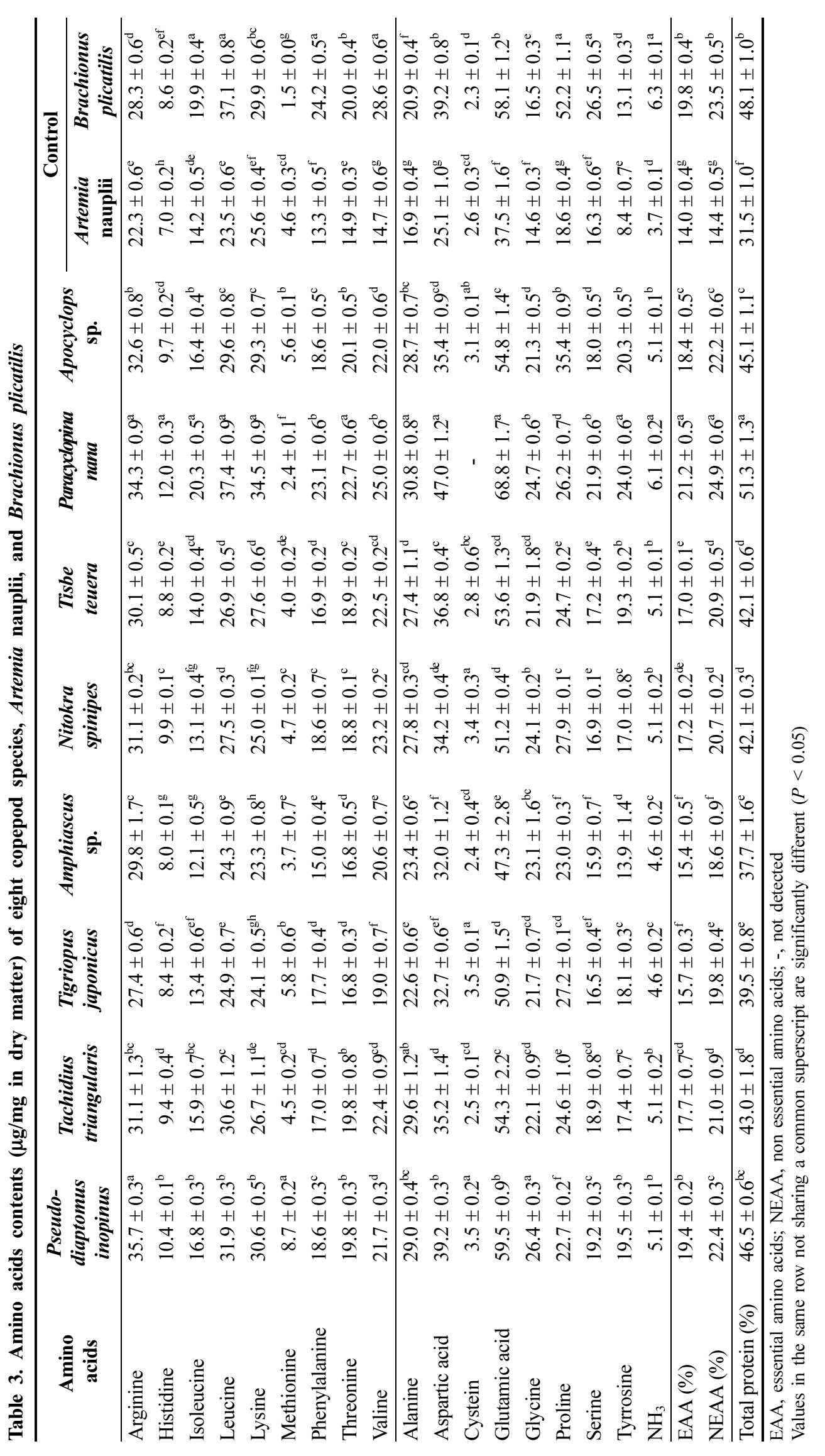




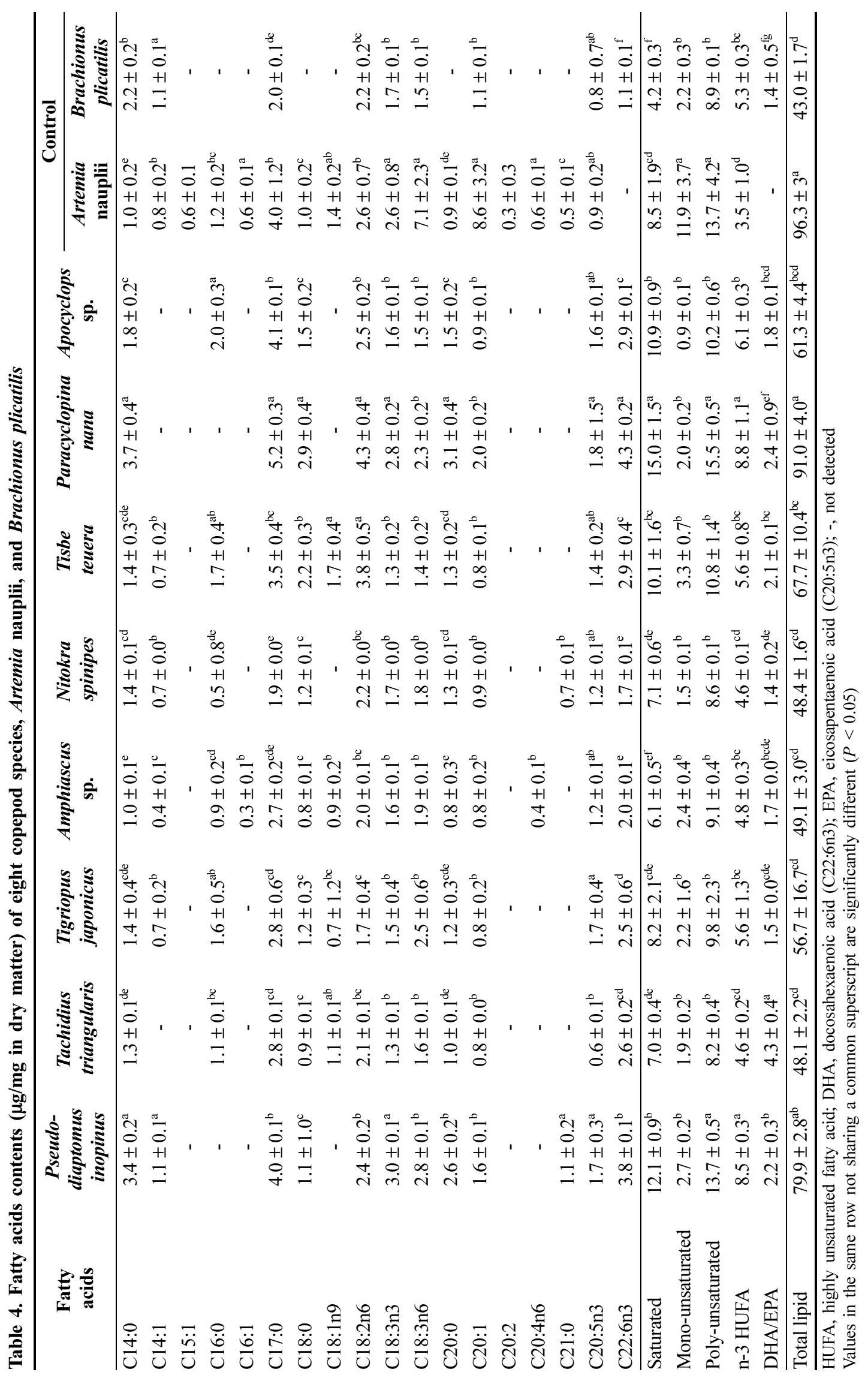


$<0.05$ ). The content of n-3 HUFA was also significantly higher in P. nana and P. inopinus at $8.8 \mu \mathrm{g} / \mathrm{mg}$ and $8.5 \mu \mathrm{g} /$ $\mathrm{mg}$, respectively, while it was the lowest in Artemia nauplii at $3.5 \mu \mathrm{g} / \mathrm{mg}(P<0.05)$. The ratio of DHA/EPA of copepods was in a range of 1.1 (P. nana) and 4.3 ( $T$. triangularis), while $B$. plicatilis had a very low ratio at 0.5. Total fat content was the highest in Artemia nauplii, $P$. nana, and $P$. inopinus in a range of $79-96 \mu \mathrm{g} / \mathrm{mg}$, while the lowest value was found in B. plicatilis at $43.0 \mu \mathrm{g} / \mathrm{mg}$.

\section{Discussion}

In this study, the body length of Apocyclops sp. nauplii in the large group was similar to that of just hatched $B$. rotundiformis, which is known as small type rotifer having a body length of ca. $120 \mu \mathrm{m}$. The body length of $P$. inopinus nauplii in the large group was similar to that of just hatched B. plicatilis (ca. $190 \mu \mathrm{m}$ ), which is known as a large-type rotifer (Yun and Hur 2011). The body length of nauplii of 5 species in the small group was in a range of 46-86 $\mu \mathrm{m}$ which was smaller than that of $B$. rotundiformis (131-166 $\mu \mathrm{m})$ (Park 1997). It has been reported that when calanoid copepod Acartia sp. nauplii, which are smaller than rotifer, was supplied to red snapper larvae Lutjanus argentimaculatus, survival of the larvae increased (Schipp et al. 1999). Therefore, from the standpoint of size, the copepod nauplii of the small group in this study seem to be adequate and suitable live food for the larvae having small mouths such as groupers and rock sea-bream.

High reproduction rate is an essential condition for live food (Cutts 2002; Fleeger 2005). Total nauplii production per gravid female of copepods in this study was the highest at 100-150 nauplii in harpacticoid such as $T$. japonicus, N. spinipes, and Amphiascus sp., whereas cyclopoid $P$. nana produced 46 nauplii, and calanoid $P$. inopinus produced less than 11 nauplii. Harpacticoid Nitokra lacustris nauplii produced, up to nauplii around 22,000 ind./L a day (Rhodes 2003). Cyclopoid Apocyclops panamensis produced more nauplii (773 ind./L) than calanoid Arcatia tonsa nauplii (325 ind./L) under the same culture condition (Lipman 2001). Also, the maximum culture density of copepod was reported as 10,000$400,000 \mathrm{ind} . / \mathrm{L}$ for harpacticoid (Støttrup 2003), as 5,000 ind./L for cyclopoid (Phelps et al. 2005), and as 100-1,000 ind./L for calanoid (Støttrup and Mcevoy 2003). The culture densities differ according to the order of copepods. Even the growth rate of copepods also varies according to the microalgal species used as live food and level of population density in mass culture, and this tendency was similar to the results on fecundity in this study.

The potential and suitability as live food depends on their nutritional compositions (Cabrera and Hur 2005; Rajkumar and Kumaraguru 2006). Sufficient protein supply is very important in the stage of first feeding after absorption of yolk (Rønnestad et al. 1999; Wright and Fyhn 2001; Aragao et al. 2004). Protein and amino acids contents in copepods are far higher than those in Artemia nauplii (Naess et al. 1995). This was confirmed in this study also as all 8 species of copepods showed higher protein contents (37.7-51.3\%) than that of Artemia nauplii $(32 \%)$. B. plicatilis has been reported to have higher protein contents than copepods (Drillet et al. 2006). In this study also, B. plicatilis showed higher protein contents than the copepods except for $P$. nana. But $P$. nana had significantly higher total protein $(51.3 \%)$ than that of $B$. plicatilis (48.1\%), which means that $P$. nana seems to be an acceptable species to substitute for the rotifer in terms of protein supply.

For normal growth and development of marine fish larvae, n-3 HUFA like EPA and DHA as essential fatty acids is required (Watanabe 1982; Rainuzzo et al. 1992; Sargent et al. 1999). It is very important to supply sufficient fatty acids for marine fishes since they cannot synthesize n-3 HUFA and n-6 HUFA from C18:0 fatty acids (Sargent et al. 1997; Rajkumar and Kumaraguru 2006; Olivotto et al. 2008). Especially, DHA is involved in normal nerve development and its functions in fish larvae particularly play an important role in retina development and vision (McEvoy et al. 1998).

In this study, EPA contents of the copepods other than T. triangularis $(0.6 \mu \mathrm{g} / \mathrm{mg})$ were higher than those of Artemia nauplii $(0.9 \mu \mathrm{g} / \mathrm{mg})$ and B. plicatilis $(0.8 \mu \mathrm{g} / \mathrm{mg})$, while DHA contents in P. nana and P. inopinus were $4.3 \mu \mathrm{g} / \mathrm{mg}$ and $3.8 \mu \mathrm{g} / \mathrm{mg}$, respectively, which was a far higher level than that in B. plicatilis $(1.1 \mu \mathrm{g} / \mathrm{mg})$ and in Artemia nauplii (not detected). Todelgo et al. (1999) has reported that EPA and DHA contents in calanoid Pseudodiaptomus sp. were higher by around 2-3 times than those in Artemia nauplii and B. plicatilis, which was similar to the results in this study. Meanwhile, AA which is a precursor of prostaglandin and plays an important role in ion transportation and osmotic pressure regulation in marine fishes and invertebrates (Castell et al. 1994) was detected in any of the species except Amphiascus sp. in this study. In fact, only Amphiascus sp. had AA contents at a level $0.4 \mu \mathrm{g} / \mathrm{mg}$ even the same food was supplied for all copepods.

Generally, marine fish larvae require food with a 
DHA:EPA ratio of around 2:1 (Mcevoy et al. 1996; Sargent et al. 1997). In this study, DHA/EPA in B. plicatilis was found to be 0.5 , which confirmed the result of Mcevoy et al. (1998). However, DHA/EPA in the copepods $T$. triangularis was as high as 4.3, while that from Apocyclops sp., T. teuera, P. inopinus, and P. nana was in a range of 1.8-2.4. Especially, $P$. nana revealed a DHA/EPA ratio of 2.4 which was lower than that fed Tetraselmis suecica (9.0) and I. galbana (11.5) (Lee 2004; Lee et al. 2006). This difference might be due to the types of microalgae supplied as food (Yang and Hur 2012).

Considering the results on size, fecundity, and nutrition of the copepods in this study, $N$. spinipes and $P$. nana seem to be suitable new live food for small mouth fish larvae such as grouper and rock sea-bream. These copepods could replace rotifer and Artemia nauplii at the hatchery. In the future, further detailed investigation is needed concerning the dietary value of these copepods with regard to marine fish larvae with various mouth sizes.

\section{Acknowledgement}

This work was supported by a Research Grant from Pukyong National University (2014). We thank Dr. Cheon-Young Chang of Daegu University for his help in identifying the copepods. We also would like to express our thanks to two anonymous reviewers for their critical comments that greatly improved the manuscript.

\section{References}

Aragao C, Conceicao LEC, Fyhn HJ, Dinis MT (2004) Estimated amino acid requirements during early ontogeny in fish with different life styles: Gilthead seabream (Sparus aurata) and Senegalese sole (Solea senegalensis). Aquaculture 242:589-605

Berg L (1997) Commercial feasibility of semi-intensive larviculture of atlantic halibut (Hippoglossus hippoglossus L.). Aquaculture 155:333-340

Budge SM (1999) Fatty acid biomarkers in a cold water marine environment. Ph.D. Dissertation, Memorial University of Newfoundland, $197 \mathrm{p}$

Cabrera T, Hur SB (2005) Effect of nutritional requirements and feeding regimes at first feeding on the survival of the larval olive flounder Paralichthys olivaceus. J Fish Sci Technol 8(4):228-234

Castell JD, Bell JG, Tocher DR, Sargent JR (1994) Effects of purified diets containing different combinations of arachidonic and docosahexaenoic acid on survival, growth and fatty acid composition of juvenile turbot (Scophthalmus maximus). Aquaculture 128:315-333

Cutts CJ (2002) Culture of harpacticoid copepods: Potential as live feed for rearing marine fish. Adv Mar Biol 44:295-316

Drillet G, Joergensen NOG, Sorensen TF, Ramloev H, Hansen BW (2006) Biochemical and technical observations supporting the use of copepods as live feed organisms in marine larviculture. Aquac Res 37:756-772

Doi M, Ohno A, Taki Y, Singhagraiwan T, Kohno H (1997) Nauplii of the calanoid copepod, Arcartia sinjiensis as an initial food organism for larval red snapper Lutjanus argentimaculatus. Suisan Zoshoku 45:31-40

Duncan DB (1995) Multiple-range and multiple F tests. Biometrics 11:1-42

Evjemo JO, Reitan KI, Olsen Y (2003) Copepods as live food organisms in the larval rearing of hailbut larvae (Hippoglossus hippoglossus L.) with special emphasis on the nutritional value. Aquaculture 227:191-210

Fleeger JW (2005) The potential to mass-culture harpacticoid copepods for use as food for larval fish. In: Lee CS, O'Bryen PJ, Marcus NH (eds) Copepods in aquaculture. Blackwell, Iowa, pp 11-24

Fraser AJ, Sargent JR, Gamble JC (1989) Lipid class and fatty acid composition of Calanus finmarchicus (Gunnerus), Pseudocalanus sp. and Temora longicornis Muller from a nutrient-enriched seawater enclosure. J Exp Mar Biol Ecolol 130:81-92

Guillard RL, Ryther JH (1962) Studies of marine planktonic diatoms. I. Cyclotella nana Hustedt and Detonula confervacea (Cleve). Can J Microbiol 8:229-239

Holt GJ (2003) Research on culturing the early life stages of marine ornamental species. In: Cato JC, Brown CL (eds) Marine ornamental species - Collection, culture and conservation. Iowa State Press, Iowa, pp 251-254

Lee KW (2004) Mass culture and food value of the cyclopoid copepod Paracyclopina nana Smirnov. Ph.D. Thesis, Kangnung National University, $125 \mathrm{p}$

Lee KW, Park HG, Lee SM, Kang HK (2006) Effects of diets on the growth of the brachkish water cyclopoid Paracyclopina nana Smirnov. Aquaculture 256:346-353

Lipman EE (2001) Production of the copepod Apocyclops panamensis under hatchery conditions. MSc. Thesis, Auburn University, $68 \mathrm{p}$

McEvoy LA, Navarro JC, Hontoria F, Amat F, Sargent JR (1996) Two novel Artemia enrichment diets containing polar lipid. Aquaculture 144:339-352

McEvoy LA, Naess T, Bell JG, Lie Ø (1998) Lipid and fatty acid composition of normal and malpigmented Atlantic 
hailbut (Hippoglossus hippoglossus) fed enriched Artemia: a comparison with fry fed wild copepods. Aquaculture 163:237-250

Morrison WR, Smith LM (1964) Preparation of fatty acid methyl esters and dimethylacetals from lipids with boron fluoride-methanol. J Lipid Res 5:600-608

Nanton DA, Castell JD (1998) The effect of dietary fatty acids on the fatty acid composition of the harpacticoid copepod, Tisbe sp., for use as a live food for marine fish larvae. Aquaculture 163:251-261

Naess T, Germian-Henry M, Naas KE (1995) First feeding of Atlantic halibut (Hippoglossus hippoglossus) using different combinations of Artemia and wild plankton. Aquaculture 130:235-250

Olivotto I, Capriotti F, Buttino I, Avella AM, Vitiello V, Maradonna F, Carnevali O (2008) The use of harpacticoid copepods as live prey for Amphiprion clarkii larviculture: Effects on larval survival and growth. Aquaculture 274: 347-352

Park HG (1997) Mass production of resting eggs of Korean rotifer, Brachionus plicatilis. Ph.D. Thesis, Pukyong National University, $115 \mathrm{p}$

Phelps RP, Sumiarsa GS, Lipman EE, Ian HP, Moss KK, Davis AD (2005) Intensive and extensive production techniques to provide copepod nauplii for feeding larval red snapper Lutjanus campechanus. In: Lee CS, O'bryen PJ, Marcus NH (eds) Copepods in aquaculture. Blackwell, Oxford, pp 151-168

Pinto CSC, Souza-Santos LP, Santos PTP (2001) Development and population dynamics of Tisbe biminiensis (Copepoda: Harpacticoida) reared on different diets. Aquaculture 198:253-267

Rainuzzo JR, Reitan KI, Jorgensen L (1992) Comparative study on the fatty acid and lipid composition of four marine fish larvae. Comp Biochem Physiol 103:21-26

Rajkumar W, Kumaraguru KP (2006) Suitability of the copepod, Acartia clausi as a live feed for seabass larvae (Lates calcarifer Bloch): compared to traditional livefood organisms with emphasis on the nutritional value. Aquaculture 261:649-658

Rhodes A (2003) Methods for high density batch culture of Nitokra lacustris, a marine harpacticoid copepod. In: Browman H, Berit Skiftesvik A (eds) 26th Annual Larval Fish Conference. IMR, Bergen, pp 449-465
Rønnestad I, Thorsen A, Finn RN (1999) Fish larval nutrition: a review of recent advances in the roles of amino acids. Aquaculture 177:201-1216

Sargent JR, Henderson RJ (1986) Lipids. In: Corner EDS, O'Hara SCM (eds) The biological chemistry of marine copepods. Oxford University Press, New York, pp 59108

Sargent JR, McEvoy LA, Bell JG (1997) Requirements, presentation and sources of polyunsaturated fatty acids in marine fish larval feeds. Aquaculture 155:117-127

Sargent JR, McEvoy LA, Estevez A, Bell JG, Bell MV, Henderson RJ, Tocher DR (1999) Lipid nutrition of marine fish during early development: current status and future directions. Aquaculture 179:217-229

Schipp GP, Bosmans JMP, Marshall AJ (1999) A method for hatchery culture of tropical calanoid copepoda, Acartia spp. Aquaculture 174:81-88

Støttrup JG (2003) Production and nutritional value of copepods. In: Støttrup JG, McEvoy LA (eds) Live feeds in marine aquaculture. Blackwell, Oxford, pp 145-205

Støttrup JG, McEvoy LA (2003) Live feeds in marine Aquaculture. Aqua Res 35:213-214

Toledo JD, Golez MS, Doi M, Ohno A (1999) Use of copepod nauplii during early feeding stage of grouper epinephalus coioides. Fish Sci 65:390-397

Watanabe T (1982) Lipid nutriton in fish. Comp Biochem Physiol 73:3-15

Wright PA, Fyhn HJ (2001) Ontogeny of nitrogen metabolism and excretion. In: Wright PA, Anderson PM (eds) Nitrogen excretion. Academic Press, London, pp 149-200

Yang SJ, Hur SB (2012) Selection of Isochrysis and Pavlova species for mass culture in high temperature season. Korean J Fish Aquat Sci 45(4):343-350

Yoo JH, Hur SB (2002) Evaluation of ciliate Euplotes sp. as a live food for marine fish larvae. Korean J Fish Aquat Sci 35(5):542-544

Yun JY, Hur SB (2011) Influence of temperature and salinity on the growth and size of the rotifer Brachionus plicatilis and B. rotundiformis. Korean J Fish Aquat Sci 44(6): 658-664

Received Apr. 21, 2014 Revised May 28, 2014 Accepted Jun. 3, 2014 